\title{
The Relation between Underwater Length and the Swimming Speed of 50 Meters Backstroke
}

\author{
Kardjono Kardjono*, Muthia Rachmawati \\ Faculty of Sport and Health Education \\ Universitas Pendidikan Indonesia \\ Bandung, Indonesia \\ *kardjono@upi.edu
}

\begin{abstract}
This research is proposed to find out the relation between the underwater length and the swimming speed of 50 meters backstroke. It used a descriptive research method. The instrument of this research is for measuring the variable which in a form of index text. Video shooting by the camera (DSLR) is done in the needs of underwater length data retrieval. The camera is placed on three different position, such as $\mathbf{5}$ meters, 10 meters, and 15 meters from the start blocks. The population in this research is $\mathbf{1 2 0}$ swimmers. They are the participants of 50 meters backstroke event in Province Olympic Swimming Championship, which are consists of female and boys age group 1(15-16 years old), age group 2 (13-14 years old), and age group 3 (12-13 years old). Based on the research result, data processing and data analytics, the conclusion of this research is: There is a firm relation between the underwater length and the swimming speed of 50 meters backstroke. By doing the underwater to the maximum, it is not only can reduce the swimming distance of the swimmer, but also can improve the swimmer swimming speed.
\end{abstract}

Keywords—underwater; swimming speed; backstroke

\section{INTRODUCTION}

In 1988 Olympic at Seoul, South Korea, swimming sports branch was shocked by 100 -meter backstroke gold medalist Suzuki Daichi, the first winner who beated the previous world record holder, David Berkoff from USA. Both of them did 3540 meters underwater swimming technique [1].

Both of two world swimmers were being underwater longer and moved faster than their opponents who swam on the water surface. What they did was rarely done by other swimmers since it means that they need to hold their breath longer while maintaining their speed in the water that can reduce their travel distance on the water surface.

The moves that was done in the water tend to give swimmers' swim rates farther than on the water surface since the swimmers' friction will be smaller if they swim in the same medium rather than swimmers who swim in two different mediums such as swimming on the water surface.

It is expected that the fly kick on the surface will generally be performed differently from the underwater dolphin kick due to the difference in the motion of the upper body between the two strokes as well as the presence of the air-water interface in the fly kick [2].
In the water, feet movement will be harder to push since there is no air to push. Both feet will push the water simultaneously to produce strong impulse. Loebbecke, explained further that "We also find that most of the thrust is produced by the feet and in both cases the down-kick produces much larger thrust than the up-kick" [2]. Counsilman Toussaint, et.al. emphasized that "The appearance of this stroke in competitive swimming is a direct consequence of the fact that swimming underwater diminishes wave drag, and can therefore give a competitive edge to the swimmer" [2].

Water has bigger density than air. Water also has bigger lift force than air. Swimmers' bodies will have smaller density than air. The large water lift force and swimmers' density are enable the swimmers to drift in the water with a little energy. Underwater friction is smaller than on the surface will enable the underwater swimmers to get smaller friction.

From Suzuki Daichi and David Berkoff cases, both of them do this technique so much farther and as a result FINA issued new regulation regarding underwater swimming [3-5]:

SW 6.3 Some part of the swimmer must break the surface of the water throughout the race, except it is permissible for the swimmer to be completely submerged during the turn and for a distance of not more than 15 meters (16.4 yards) after the start and after each turn. By that point, the head must have broken the surface of the water.

Eventhough FINA regulates the maximum underwater distance no more than 15 meters, not all swimmers are able to maximize it well [4]. It is possibly caused by the difference of each swimmers' ability, or their swimming speed on the water surface is better than their underwater double kick. Based on this problem, a study to investigate whether underwater distance has significant correlation with 50 meters backstroke swimming speed.

\section{METHOD}

\section{A. Subjects}

The subjects employed in this research are all Province Olympic Swimming Championship swimming athletes, which consists of 47 women and men swimmers age group 1 (15-16 years old) and 39 swimmers age group 2 (13-14 years old). 


\section{B. Test Design}

The data was collected from 3 videos taken by camera put beside the swimming pool and was focused on the 5 meters, 10 meters, and 15 meters marks started from start block in order to measure the underwater distance. Meanwhile, the swimmers' speed were measured by electro timer on the finish wall [6].

\section{Statistical Analysis}

SPSS 16 for Windows was used as the technique in analyzing the data. The first step was to find its descriptive statistic, the second was to find normality test data and coefficient correlation of significance test.

\section{RESULTS}

The statistical data of coefficient correlation of significance test shows whether the data from the field brings out significance results or not. The tables below show the result of coefficient correlation of significance test data processing result:

TABLE I. THE RESULT OF COEFFICIENT CORRELATION OF SigNifICANCE TEST (R) BETWEEN THE LENGTHS OF UNDERWATER AND THE SWIMMING SPEEd of 50 METERS BACKSTROKE STYLE IN MEN AGE GROUP OF $15-16$

\begin{tabular}{|c|l|l|c|c|c|}
\hline Variable & Correlation & Sig Value & $\boldsymbol{\alpha}$ & Evidence & Results \\
\hline Under Water & -0.717 & 0.028 & 0.05 & Ho is rejected & Significant \\
\hline Time & & & & & \\
\hline
\end{tabular}

TABLE II. The CALCULATION RESUlt OF COEFFICIENT CORRELATION OF SIGNIFICANCE TEST (R) BETWEEN THE LENGTHS OF UNDERWATER AND THE SWIMMING SPEED OF 50 METERS' BACKSTROKE STYLE IN WOMEN AGE GROUP OF 15-16.

\begin{tabular}{|c|l|l|c|c|c|}
\hline Variable & Correlation & Sig value & $\boldsymbol{\alpha}$ & Evidence & Results \\
\cline { 1 - 3 } Under Water & -0.717 & 0.000 & 0.01 & Ho is rejected & Significant \\
\hline Time & & & & & \\
\hline
\end{tabular}

TABLE III. THE CALCULATION RESULT OF COEFFICIENT CORRELATION OF SIGNIFICANCE TEST (R) BETWEEN THE LENGTHS OF UNDERWATER AND THE SWIMMING SPEED OF 50 METERS' BACKSTROKE STYLE IN MEN AGE GROUP OF $13-14$.

\begin{tabular}{|c|c|c|c|c|c|}
\hline Variable & Correlation & Sig value & $\alpha$ & Evidence & Results \\
\hline Under Water $(X)$ & \multirow{2}{*}{-0.268} & \multirow{2}{*}{0.217} & \multirow{2}{*}{0.05} & \multirow{2}{*}{$\begin{array}{c}\text { Ho is } \\
\text { accepted }\end{array}$} & \multirow{2}{*}{$\begin{array}{c}\text { Not } \\
\text { significant }\end{array}$} \\
\hline Time $(Y)$ & & & & & \\
\hline
\end{tabular}

TABLE IV. THE CALCULATION RESUlT OF COEFFICIENT CORRELATION OF SIGNIFICANCE TEST (R) BETWEEN THE LENGTHS OF UNDERWATER AND THE SWIMMING SPEED OF 50 METERS' BACKSTROKE STYLE IN WOMEN AGE GROUP OF 13-14.

\begin{tabular}{|c|l|l|c|l|c|}
\hline Variable & Correlation & Sig Value & $\boldsymbol{\alpha}$ & Evidence & Results \\
\hline Under Water & -0.602 & 0.014 & 0.05 & $\begin{array}{l}\text { Ho is } \\
\text { rejected }\end{array}$ & Significant \\
\hline Time & Sime &
\end{tabular}

TABLE V. THE CALCUlation Result OF COEFFICIENT CORRELATION OF SigNIFICANCE TEST (R) BETWEEN THE LENGTHS OF UNDERWATER AND The Swimming SPEed Of 50 Meters' BACKSTROKe StYle In MEN AGE GROUP OF 11-12.

\begin{tabular}{|c|c|c|c|c|c|}
\hline Variable & Correlation & Sig Value & $\alpha$ & Evidence & Results \\
\hline Under Water & \multirow{2}{*}{-0.381} & \multirow{2}{*}{0.146} & \multirow{2}{*}{0.05} & & \multirow{2}{*}{ Not significant } \\
\hline Time & & & & accepted & \\
\hline
\end{tabular}

TABLE VI. THE CALCULATION RESUlT OF COEFFICIENT CORRELATION OF SIGNIFICANCE TEST (R) BETWEEN THE LENGTHS OF UNDERWATER AND THE SWIMMING SPEED OF 50 METERS' BACKSTROKE STYLE IN WOMEN AGE GROUP OF 11-13.

\begin{tabular}{|c|l|l|c|l|l|}
\hline Variable & Correlation & \multicolumn{1}{|c|}{ Sig Value } & $\boldsymbol{\alpha}$ & Evidence & Results \\
\hline Under Water & -0.404 & 0.097 & 0.05 & $\begin{array}{l}\text { Ho iscepted is } \\
\text { Time }\end{array}$ & $\begin{array}{l}\text { Not } \\
\text { significant }\end{array}$ \\
\hline
\end{tabular}

TABLE VII. THE CALCULATION RESUlT OF COEFFICIENT CORRELATION OF SIGNIFICANCE TEST (R) BETWEEN THE LENGTHS OF UNDERWATER AND THE SWIMMING SPEEd OF 50 METERS' BACKSTROKE STYLE IN MEN AND WOMEN.

\begin{tabular}{|c|l|l|c|l|c|}
\hline Variable & Correlation & Sig Value & $\boldsymbol{\alpha}$ & Evidence & Results \\
\hline Under Water & -0.508 & 0.000 & 0.01 & $\begin{array}{l}\text { Ho is } \\
\text { rejected }\end{array}$ & Significant \\
\hline Time & &
\end{tabular}

\section{DISCUSSION}

From the results of the overall samples of men and women aged 15-16, it can be concluded that there is a negative and significant relationship. If the underwater length is further, then the time or the speed will be better. This is possible because the underwater length is at most 15 meters, it will reduce the distance the swimmer has to cover to 35 meters only from the overall distance of 50 meters. The effect that would happen is that if dolphin kick was done underwater, it would push the swimmer more rather than doing the dolphin kick on the surface. This is because in the water, the feet would push harder because there is no air to push, both legs would push the water simultaneously producing a stronger boost. Meanwhile results from the table of men's age group 13-14 and men and women's age group 11-12 shows that these age groups have a negative but not significant relationship between the length of underwater and the swimming speed of 50 meters backstroke style. However in overall age groups, the result shows that there is a negative and very significant relationship between the length of the underwater and the speed in 50 meters backstroke style.

The age group number 3 of men and women is stated as not significant, the age in the age group is classified as too young that is 11-12 years old. The average age is still in the preadolescent in which the growth period is still growing in terms of physical and psychological. In that average age, swimmers are in their first period that is generalised, in which the students will focus on the techniques, strokes, starts, tumble turns, and streamline.

The good posture and the height or the weight of the body is unstable because they are still in their growth period. Therefore, in that age group, the coach has to know the effect of the training to the students' body system and know their physical and psychological needs because each student develops with different accelerations. The comparison between underwater and swimming is that there is more swimming. However, for the young age groups, for example group 3, they don't pay much attention to techniques or advanced skills such as underwater. They are only focused in improving their swimming techniques and their swimming speed without paying attention to other things that support their swimming speed. 


\section{CONCLUSION AND SUGGESTION}

The research that has been conducted has shown that there is a significant correlation between the length of underwater and swimming speed of 50 meters' backstroke style.

Underwater can affect the swimmer's speed of 50 meters' backstroke style. Therefore, the swimmer in every age groups have to get this training frequently to improve and maximizing the length of underwater according to FINA rules, that is 15 meters [4]. Hence, the distance the swimmer has to cover will be reduced to increase the swimmer's speed.

\section{REFERENCES}

[1] Wikipedia, 1988 Summer Olympics. [Online]. Accessed from https://en.wikipedia.org/wiki/1988_Summer_Olympics, 2018, 15 January.

[2] A. Von Loebbecke, R. Mittal, F. Fish, R. Mark, A Comparison of The Kinematics of The dolphin Kick in Humans and Cetaceans. The George Washington University; Human Movement Science 28 (99-112), 2009.

[3] Sport Reference LLC, Daichi Suzuki. Available: https: //www.sportsreference.com/olympics/athletes/su/daichi-suzuki-1.html [30 January 2018]. 2016.

[4] FINA (2013-2017). Peraturan Renang FINA. Bandung

[5] D. Haller, Belajar Berenang. Bandung: Pionir Jaya, 2006.

[6] Sugiyono, Metode Penelitian Kuantitatif, Kualitatif, dan R\&D. Bandung: Alfabeta, 2017. 